\title{
Separatist Creditors Problems on Postponement of Debt Payment Obligations Based on the Supreme Court's Decree Number 30/KMA/SK/I/2020
}

\author{
Suwinto Johan \\ Faculty of Business, President University, Indonesia, \\ E-mail: suwintojohan@gmail.com
}

Submitted: June 3, 2020; Reviewed: October 21, 2020; Accepted: October 22, 2020

\section{Article Info}

Keywords:

Concurrent, Indonesian Bankruptcy

Law, Postponement of Debt

Payment Obligation.

DOI:

10.25041/fiatjustisia.v15no3.1956
Debt Payment Obligation postponement is an effort for creditors and debtors to settle the debts with a more efficient process. The creditor of a company consists of concurrent and separatist creditors. Based on the Supreme Court Decree Number 30/KMA/SK/I/2020 Book I on the Guidelines for the Settlement of Requests for Bankrupt and Postponement of Debt Payment Obligation of the Supreme Court of the Republic of Indonesia, the creditors who can submit Postponement of Debt Payment Obligation (PKPU) are only concurrent creditors. The separatist creditors are not allowed to submit PKPU. This is different from the Bankruptcy and the Postponement of Debt Payment Law Number 37 of 2004. Based on Law Number 37 of 2004, Creditors who can submit Postponement of Debt Payment Obligation are creditors who estimate that the debtor cannot continue to pay debts that are due and can be billed, can request that the debtor be given a postponement of debt payment, to enable the debtor to submit a reconciliatory proposal which includes offering the payment of part or all of the debt to the creditor. However, based on the Supreme Court Decree, only the concurrent creditor can submit Debt Payment Obligation's postponement. As a result of this Supreme Court Decree, the separatist creditors cannot apply for Debt Payment Obligation postponement. Separatist creditors can propose the postponement of debt payment obligations if the separatist creditor has turned into a concurrent creditor. Separatist creditors become concurrent creditors if the collateral provided value 
is insufficient for the company's obligations so that the separatist creditors can propose to be part of the concurrent creditors. By becoming a concurrent creditor, the separatist creditors can submit to be part of the peace proposal and distribute the remaining company assets.

\section{A. Introduction}

In 1998, Indonesia experienced a monetary crisis, where many companies experienced financial problems. Many companies have also proposed debt restructuring. Debt restructuring is carried out between individual companies and creditors. Debt restructuring settlement requires a long time. Each creditor has different interests with loan tenures, guarantees, interest rates, currencies, and different types of loans.

Many of these companies have good business prospects for the future. We can mention companies like Astra International, which must carry out debt restructuring as well. Companies that have prospects only require a period of debt payment delays for a while. Company management requires leeway rather than creditors to focus on doing business at this time. Some foreign creditors threaten to default on loan agreements made. The legal certainty and precautionary principle carried out by these financial institutions can make a very impactful contribution, significantly minimizing the occurrence of banks that have systemic or non-systemic impacts. ${ }^{1}$

If there is one creditor who threatens to default, then all loans will potentially be cross-default. If all facilities are default, the restructuring process is very complicated. Furthermore, the company will experience financial distress, even though it is profitable and will have good prospects. If it is declared default, it will be submitted to the court, and then a civil route will be taken. The settlement will also require a long time.

The government issued a movement known as the Jakarta Initiative. The Jakarta Initiative will be the mediator of negotiations between creditors and debtors. At that time, many foreign creditors forced payment of their portion as soon as possible. Meanwhile, the US Dollar foreign exchange rate against the Rupiah has reached almost 7 times from 2,200 IDR to 14,700 IDR. The ability of companies to be very limited to be able to pay their debts. If the exchange rate depreciates, then the company will have the ability to pay in instalments.

With time, some companies can run their businesses normally again, without going through restructuring. This is due to the negotiation process's length and economic conditions, which began to improve in early 2000. The

\footnotetext{
${ }^{1}$ Z. D. Zaini \& Lukmanul Hakim, "Prevention and Handling of the Crisis of Financial Systems in Banking Institutions", Fiat Justisia: Jurnal Ilmu Hukum 13, no. 2 (2019): 151-166, DOI: 10.25041/fiatjustisia.v13no2.1567.
} 
economic cycle repeated and turned into an economic turmoil in 2004 with the increase in fuel, the global crisis in 2008, and the pandemic COVID-19 outbreak in the year 2020.

As stated in Law Number 37 of 2004 concerning Bankruptcy and the Postponement of Debt Payment Obligations, the primary considerations are:

1. The need for the development of national law to create a just and prosperous society based on the Pancasila and the 1945 Constitution of the Republic of Indonesia must be able to support and guarantee certainty, order, enforcement, and legal protection that is centred in justice and truth;

2. With the rapid development of the economy and trade, more and more debt problems arise in the community;

3. The monetary crisis that occurred in Indonesia had an unfavourable impact on the national economy, causing enormous difficulties for the businesses in settling debts to continue their activities;

4. As one of the legal means for the settlement of debts and receivables, the Law on Bankruptcy (Faillissements-verordening, Staatsblad 1905: 217 juncto Staatsblad 1906: 348) most of the material is no longer following the development and legal requirements of the people and Government Regulations Substituting Law Number 1 of 1998 concerning Amendment to the Law on Bankruptcy, which was later stipulated to become Law under Law Number 4 of 1998, but the amendment has not yet fulfilled the development and legal needs of the community.

As the basis for the considerations above, it is clear that the Postponement of Debt Payment Obligations Law aims to provide certainty, orderliness, enforcement, and legal protection with the core of justice and truth. Besides, it aims to resolve the problem of debts and receivables in the community. As explained in the background, the experience of the 1998 crisis has caused many problems in the settlement of debts in the business world in Indonesia. The government established the law so that the national economy can settle its debts and receivables properly to run its business. Also, the existing legal facilities are not yet perfectly aligned with people's development and legal needs. A clean facility is needed that can settle debts through social development. Composition in bankruptcy aims to make the debtor bankrupt to conciliate with creditors who stipulated that the debtor bankrupts to pay something specific percentage of the debt. He will be freed to pay the rest. ${ }^{2}$

Starting 14th January 2020, based on the Supreme Court of the Republic of Indonesia Decree Number 30/KMA/SK/I/2020 Book I on the Guidelines for the Settlement of Requests for Bankrupt and Postponement of Debt Payment Obligations, those who can submit The Postponement of Debt

${ }^{2}$ Ida Nadirah, Bismar Nasution, "Composition Bankruptcy As Realization Principles of Balance Between Debtor and Creditor", South East Asia Journal of Contemporary Business, Economics and Law 11, no. 4 (2016): 1-10, 1. 
Payment Obligations are concurrent creditors. With a Supreme Court Decree, separatist creditors cannot submit The Postponement of Debt Payment Obligations again. The government provides legal certainty to defend the banks or creditors and debtors. In contrast, the efforts that can be taken to resolve troubled banks or financial institutions can be made by reconditioning, restructuring, and rescheduling. ${ }^{3}$

Based on the explanation above, this study has the following research questions:

1. Why can't separatist creditors submit Postponement of Debt Payment Obligations?

2. How can separatist creditors participate in the Postponement of Debt Payment Obligations submission process by concurrent creditors?

3. How can separatist creditors submit The Postponement of Debt Payment Obligations?

The objectives of this research that can be achieved by solving the problems above are:

1. To discover the background of separatist creditors, they cannot submit the Postponement of Debt Payment Obligations.

2. To provide proposals to separatist creditors in the Postponement of Debt Payment Obligations process.

3. To provide proposals to separatist creditors to submit the Postponement of Debt Payment Obligations.

The research was conducted with a normative legal research method with a descriptive-analytical approach. ${ }^{4}$ The study will be based on primary, secondary, and tertiary data regarding the secured and unsecured debt agreement when the debtor is in bankruptcy or reorganization. The data is considered of legal materials such the court decision and research journals.

\section{B. Discussion}

\section{Debt and Receivables of Companies}

All companies require working capital to develop their businesses. Working capital is obtained from shareholders' initial capital, retained earnings, and loans obtained from the money market and capital market. Loans are the primary source because they have lower compensation (expected return) than other funding sources. Sources of funding from

\footnotetext{
${ }^{3}$ Lukmanul Hakim, "The Alternative Model Settlement of Credit Problems in Banking Agencies", Fiat Justisia: Jurnal Ilmu Hukum 12, no. 2, (2018): 143-155, DOI: 10.25041/fiatjustisia.v12no2.1299.

${ }^{4}$ Gunardi Lie, et.al., "Problematika UU No. 37 Tahun 2004 Tentang Kepailitan dan PKPU Terhadap Bank Sebagai Kreditor Separatis", Jurnal Bakti Masyarakat Indonesia 2, no. 2 (2019): 159-168, DOI: 10.24912/jbmi.v2i2.7242.
} 
shareholders will have a higher expected return than loans because of their position on the company's balance sheet's debit side.

The shareholders' responsibility will be dependent on the type of the entity; for limited liabilities, the company will have different treatment compared to the type of the firm. In bankruptcy, partner Liabilities mean that unlimited partner is liable for receivables to personal assets. An unlimited partner who invests capital in a partnership and involves personal property is included in the act of agreeing. ${ }^{5}$

Funding from the money market or banking funding is the most preferred alternative source because of the ease in the credit process. Capital market funding requires a longer process and particular requirements. Capital market funding also tends to be accessible only to large companies. Capital market funding can take the form of bond loans or conducting an initial public offering.

However, funding from banks requires collateral. Almost all loans obtained from banks in Indonesia require collateral. There are some small alternatives such as a Non-Collateral Loan, which individuals can obtain, and the use of credit cards that do not require collateral. However, the amount of money that can be borrowed from Non-Collateral Loan and credit cards is small.

All loans for working capital for a company will require collateral. Most of the guarantees requested are collateral for fixed assets such as land or buildings. At the moment, land and buildings are the safest collaterals because they are fixed assets. Other collaterals, such as motorized vehicles, machines, or securities such as shares, receivables, or guarantees, are personal or corporate (Personal Guarantee or Corporate Guarantee). In a credit agreement, the creditor wants a guaranteed guarantee of debt by obtaining legal certainty with the general agreement as Article 1131 and 1132 of the Civil Code. The creditors still need collateral. ${ }^{6}$

In some instances, creditors can protect themselves from Loss's risk from bankruptcy or restructuring by slightly raising contract interest rates. ${ }^{7}$ Also, based on Bank Indonesia Regulation Number 7/2/PBI/2005 concerning Asset Quality Assessment of Commercial Bank Loans, where that can be calculated as a deduction in the establishment of Allowance for Possible Losses are:

\footnotetext{
${ }^{5}$ P. Dona, "Juridical Analysis of Partner Liabilities in Bankruptcy Process at CV AGro Sawita Mandiri Perkasa", International Journal of Multicultural and Multireligious Understanding 6 no. 3 (2019): 96-104, DOI: 10.18415/ijmmu.v6i3.771.

${ }^{6}$ S. Redjeki Slamet, "Perlindungan Hukum dan Kedudukan Kreditor Separatis Dalam Hal Terjadi Kepailitan Terhadap Debitor", Forum Ilmiah Jurnal Bunga Rampai 13, no. 1 (2016): 104-114, 112.

${ }^{7}$ S. Scott Waltraud, "Deferred Cash Payments to Secured Creditors in Cram Down of Chapter 11 Plans: A Matter of Interest", Washinton Law Review 64, no. 4 (1988): 1041-1061, 1041.
} 
a. Securities and shares that are actively traded on a stock exchange in Indonesia or have an investment rating and are bound with a pledge;

b. land, residential property, and buildings bound by a pledge;

c. aircraft or ships with a size of more than 20 (twenty) cubic meters bound with by a pledge; and or

d. motor vehicles and fiduciary bound supplies.

Based on Article 44 (2), the amount of PPA is determined to be at least:

a. 5\% (five per cent) of Assets classified with Special Supervision quality, after deduction for collateral value;

b. $15 \%$ (fifteen per cent) of Assets with Substandard quality after deduction for collateral value;

c. $50 \%$ (fifty per cent) of Assets of Doubtful quality after deduction for collateral value;

d. $100 \%$ (one hundred per cent) of Assets classified Loss, after deduction for collateral value.

Based on this regulation, banks require collateral to deduce the Allowance for Active Losses (PPA). If there is no collateral, then banks are required to set aside a maximum reserve for loans.

\section{Legal Doctrine on Postpone of Debt Payment Obligation}

In debt and receivables or credit lending, the creditor and the debtor signs an agreement. This agreement is similar to a legal document that has to fulfil at least three elements, as stated by Gustav Radbruch, namely justice, expediency, and legal certainty. Both parties want the achievement of justice, expediency, and legal certainty between the debtor as the borrower and the creditor as the lender. Both parties have an equal position. Also, the weight of the legal idea, according to Radbruch, is justice in the form of guarantees and legal protection. ${ }^{8}$

The Postponement of Debt Payment Obligations Law aims to enforce the law of debit and credit. Some debtors have good intentions with creditors who do not have good intentions or vice versa. Some creditors have good intentions with debtors who do not have good intentions. Some debtors are committed to continuing their business and responsible for their debts. But there are also creditors with bad intentions who plan to take over the debtor's business because the debtor's business is very prospective.

Conversely, there are also bad debtor's intentions by doing side streaming funds. The transfer of bank loan funds to the company is used for personal interests beyond what was promised to the creditors. Creditors have good faith and have lost confidence in the debtors who deliberately do it and let the

\footnotetext{
${ }^{8}$ Tristam P Moeliono dan Tanius Sebastian, "Tendensi Reduksionis dan Utilitarianis dalam Ilmu Hukum Indonesia: Membaca Ulang Filsafat Hukum Gustav Radbruch", Paper presented at the 5th National Conference of the Indonesian Legal Philosophy Association. Solo, (2015).
} 
company go bankrupt by creditors. With the Postponement of Debt Payment Obligations Law, this can be resolved better and more efficiently.

One of the objectives of the Postponement of Debt Payment Obligations Law is to uphold justice. All laws aim to uphold justice for a community or society. John Rawls argues that justice can only be upheld if the state implements the principle of justice: everyone should have the same right to obtain fundamental freedoms; social and economic differences should be arranged in such a way as to provide significant benefits for those who are not fortunate, and positions and rank are open to all people based on equal opportunity. ${ }^{9}$

Aristotle formulated justice, which distinguishes between distributive justice and collective or remedial justice, which is the basis for all theoretical discussions on the subject matter. Distributive justice refers to distributing goods and services to each person by his position in society and equal treatment of equality before the law.

\section{The Background of Separatist Creditors Unable to Apply for Postponement of Debt Payment Obligations}

Creditors are categorized into two categories, namely separatist creditors and concurrent creditors. Concurrent creditors are creditors who have loans or bills to debtors without collateral. This type of creditor is generally a creditor for trade receivables. This type of debt is short-term debt.

A separatist creditor is a creditor who has collateral. Separatist creditors are generally creditors of both bank and non-bank financial institutions and have medium to long-term debt. The term separatist is a group of people who try to divide the group/nation's unity to get support. Based on this description, it can be said that separatists can be interpreted separately, sole or unique, or primary. Based on chapter 20, Law No. 42 of 1999, regarding the fiduciary transfer, the secured creditor has the right to execute the fiduciary right if the debtor is under bankruptcy or default condition. ${ }^{10}$

Based on the above definition, the separatist creditor's position is separate. Separatist creditors are creditors who provide loans with collateral. This collateral is separate from the other collateral. Separatist creditors have exclusive rights. Separatist creditors are also called secured creditors or creditors with collateral. With this position, the separatist creditor is not required or does not have pari passu obligations with other creditors in the case of collateral.

\footnotetext{
9 Inge Dwisvimiar, "Keadilan Dalam Perspektif Filsafat Ilmu Hukum", Jurnal Dinamika Hukum 11, no. 3 (2011): 520-530, DOI: 10.20884/1.jdh.2011.11.3.179.

${ }^{10}$ Dewanto R. Fluorentinus., "Kedudukan Kreditur Selaku Penerima Jaminan Fidusia Dalam Hal Debitur Pailit", Thesis, Program Studi Magister Kenotariatan, Universitas Diponegoro (2009).
} 
With this special privilege, the separatist creditor has the right to execute the collateral given if it turns out that the debtor has defaulted. Based on article 21 Law No. 4 of 1996 concerning mortgage rights, it is stated that if the debtor is bankrupt, the separatist creditor of the right mortgage holder directly sells the object to be guaranteed by the mortgage called parate execution in the theory of bankruptcy law. ${ }^{11}$ The collateral property of a third party cannot be entered as a boedel bankrupt debtor. A third party guarantee is not the borrower's property anymore; it is used as the basis of legal considerations for the judge to decide the bankruptcy case. ${ }^{12}$

Separatist creditors do not need the support or participation of other parties to execute collateral, which is different from Law Number 37 of 2004. The execution right of a secured creditor is suspended. The secured creditor's rights are still guaranteed by the Indonesia Bankruptcy Law and the transfer of the executorial right from a secured creditor to the curator. ${ }^{13}$

Every creditor submitting Postponement of Debt Payment Obligations aims to be able to get their money back. Separatist creditors do not need to execute this method. Based on Article 55 (1) of Law Number 37 of 2004, every creditor holding a lien, fiduciary guarantee, mortgage, or another collateral right, can execute his rights as if bankruptcy does not occur. Thus, the separatist creditor does not have the privilege to follow the Postponement of Debt Payment Obligations process.

As the separatist creditor, the bank has a particular and irrevocable position. Rights on the collateral pledged against it - the preemptive right of wage workers with a pre-emptive right when an enterprise is declared bankrupt or liquidated. ${ }^{14}$ Based on Labor Law, the workers have the legal status as preferred creditors who are entitled to prioritize payment in the distribution of bankrupt assets strengthened by the results of a judicial review in Decision of the Constitutional Courts Number 67/PUU-XI/2013. The right of workers to wages is prioritized and calculated from collateral objects, which are separatist creditors' rights. ${ }^{15}$

\footnotetext{
${ }^{11}$ Nina Yolanda, "Analisis Yuridis Hak Kreditor Separtis Pemegang Hak Tanggungan Dalam Kepailitan”, Jurnal Litigasi 14, no. 2 (2013): 1937-1974, DOI: 10.23969/litigasi.v14i2.86.

12 Rahayu Hartini, "Legal Status of Bank Guarantee on Behalf of Third Parties in the Bankruptcy Perspective", Yustisia 6, no. 1 (2017): 190-198, DOI: 10.20961/yustisia.v6i1.11530.

${ }^{13}$ Udin Silalahi, Claudia, "Kedudukan Kreditor Separatis atas Hak Jaminan Dalam Proses Kepailitan", Masalah-Masalah Hukum 49, no. 1 (2020): 35-47, DOI: 10.14710/mmh.49.1.2020.35-47.

${ }^{14}$ I. Wayan Sukarta, "Kedudukan dan Hak Bank terhadap Hak Preferen Upah Buruh Dalam Kepailitan", Jurnal Magister Hukum Udayana (Udayana Master Law Journal) 6, no.3. (2017): 300-309, DOI: 10.24843/JMHU.2017.v06.i03.p03.

15 R. Murniati, D. Selvya C, "Separatist Creditors vs. Preferred Creditors Rights in the Bankruptcy Case Based on the Decision of Constitutional Court of 2013" Fiat Justisia: Jurnal Ilmu Hukum 13, no. 3 (2019): 231-240, DOI: 10.25041/fiatjustisia.v13no3.1616.
} 


\section{The Participation of Separatist Creditor in Postponement of Debt Payment Obligations Process}

Based on Article 229 (1) of Law No. 37 of 2004, granting a postponement of the obligation to pay the fixed debt and its extension is determined by the court based on approval of more than $1 / 2$ (one half) the number of concurrent creditors whose rights are recognized or temporarily recognized are present and represent at least $2 / 3$ (two thirds) part of all claims recognized or provisionally recognized from concurrent creditors or proxies present at the hearing; and approval of more than 1/2 (one half) of the number of Creditors whose receivables are guaranteed by a pledge, fiduciary security, liability, mortgage, or other collateral rights that are present and represent at least $2 / 3$ (two thirds) of the entire bill the creditors or their attorneys present at the hearing.

If voting involves separatist or privileged creditors, it is carried out because, based on article 246, the provisions on the postponement of debt repayment obligations apply mutatis mutandis to the exercise of privileged creditors and creditors, provided that the suspension applies during the postponement of debt payment obligations. The creditors' position had no voice in the decision-making peace effort in Act No. 37 the Year 2004 on Bankruptcy and Suspension of Payment. The Supreme Court's basis considers it essential to pay attention to creditors' voting rights in decision-making that separates peace efforts. ${ }^{16}$ Bargaining between secured and unsecured creditors can distort the reorganization or restructuring process. ${ }^{17}$

However, based on Article 244, the postponement of debt payment obligations does not apply to bills guaranteed by a pledge, fiduciary collateral, liability, mortgage, or other collateral rights; bills for maintenance, supervision, or education fees that must be paid and the Supervisor Judge must determine the number of bills that have been and have not been paid before delays in debt payment obligations that do not bill with privileges; and claims that are privileged for particular objects belonging to the debtor or all Debtor assets.

\section{Postponement of Debt Payment Obligations Submission by Separatist Creditor}

However, separatist creditors can become concurrent creditors as Article 189 (5) if the proceeds from the sale of objects are insufficient to pay all

\footnotetext{
${ }^{16}$ Kemala A Hayati, et.al., "Hak Suara Kreditor Separatis Dalam Proses Pengajuan Upaya Perdamaian Menurut Undang-Undang Nomor 37 Tahun 2004 Tentang Kepailitan dan Penundaan Kewajiban Pembayaran Utang”, USU Law Journal 14, no. 1 (2016): 116-126.

${ }^{17}$ Kenneth M. Ayotte \& Edward R. Morrison, "Creditor Control and Conflict in Chapter 11", Journal of Legal Analysis 1, no. 2. (2009): 511-551, 511, DOI: 10.1093/jla/1.2.511.
} 
creditors' creditors prioritized, so for their shortcomings, they are designated as concurrent creditors.

On the contrary, based on Article 199, in the case of an object upon which certain privileges, pawn, fiduciary collateral, mortgage, or other collateral rights are sold, after being given to the creditor, that precedence is given a distribution according to Article 189 at the time the distribution is made again, the proceeds from the sale of these objects will be paid to them at the highest value of the priority rights after deducting the amount received previously.

Under section 200 of the Bankruptcy and the Postponement of Debt Payment Obligations Law, creditors have the right to advance. They lose the right to the proceeds of the goods' sale if the proceeds of a prior subdivision have been provided to other creditors first. If this happens, then the right creditor or the separatist creditor will be the concession creditor. The collateral execution difficulties when the debtor is bankrupt is the municipal auction office did not ready the selling auction collateral of guaranteed right without authorization from the Chairperson of Region Court. Some of the debtors who have no goodwill will appeal to the district court to prolong and execute the execution. ${ }^{18}$

\section{Conclusion}

Privileged creditors or separatist creditors are creditors who have special privileges or have guarantees that have been determined at the time the agreement was made so that separatist creditors cannot submit the postponement of debt payment obligations. Separatist creditors can propose the postponement of debt payment obligations if the separatist creditor has turned into a concurrent creditor. Separatist creditors become concurrent creditors if the collateral provided value is insufficient for the company's obligations so that the separatist creditors can propose to be part of the concurrent creditors. By becoming a concurrent creditor, the separatist creditors can submit to be part of the peace proposal and participate in distributing the remaining company assets.

Concurrent creditors are creditors who do not have special privileges or guarantees. A separatist creditor can turn into a concurrent creditor if the collateral that has been pledged is also collateral to other creditors. Therefore, the separatist creditor becomes a concurrent creditor. Separatist creditors can propose to be concurrent creditors if the amount of debt billed is reduced by the proceeds from collateral sale. There are still those not billed, thus becoming a portion that can be billed as a concurrent creditor.

\footnotetext{
${ }^{18}$ Rully Afraldo Daely, Ramli Siregar, Windha Windha, "Kedudukan Benda Jaminan Yang Dibebani Hak Tanggungan dan Eksekusi Benda Jaminan Dalam Hal Debitur Pailit", Transparency, Jurnal Hukum Ekonomi 3, no. 2 (2014): 1-10.
} 
In determining the status of delaying debt payment obligations, separatist creditors are involved in voting because delaying the payment of debt obligations is also obligations of separatist creditors.

\section{Recommendations}

Financial institutions that provide loans by obtaining privileges or have the collateral need to assess the collateral value. The collateral value must be adequate for the value of the loan provided. Loan agreement with collateral must be bound following the existing legislation. Thus, financial institutions, both banks, and non-banks will continue to be separatist creditors in the event of a postponement of debt payment obligations.

\section{References}

Ayotte, Kenneth M., Morrison, Edward R. "Creditor Control and Conflict in Chapter 11", Journal of Legal Analysis 1, no. 2, 2009: 511-551, DOI: 10.1093/jla/1.2.511.

Bank Indonesia Regulation Number 7/2/PBI/2005 on the Asset Quality Assessment of Commercial Bank Loans

The Constitutional Courts Number 67/PUU-XI/2013 on the Position of Separatist Creditor, especially Worker Wages.

Dona, P., Daulay, Z., Ulfanora. "Juridical Analysis of Partner Liabilities in Bankruptcy Process at CV AGro Sawita Mandiri Perkasa", International Journal of Multicultural and Multireligious Understanding 6, no. 3, 2019: 96-104, DOI: 10.18415/ijmmu.v6i3.771. Fluorentinus, Dewanto R. "Kedudukan Kreditur Selaku Penerima Jaminan Fidusia Dalam Hal Debitur Pailit", Thesis, Program Studi Magister Kenotariatan, Universitas Diponegoro, 2009.

Inge Dwisvimiar, "Keadilan Dalam Perspektif Filsafat Ilmu Hukum", Jurnal

Dinamika Hukum 11, no. 3, 2011: 520-530, DOI: 10.20884/1.jdh.2011.11.3.179.

Johan, Suwinto, Merger Akuisisi dan Restrukturisasi, Bogor: IPB Press, 2018. Kemala A Hayati, et.al., "Hak Suara Kreditor Separatis Dalam Proses Pengajuan Upaya Perdamaian Menurut Undang-Undang Nomor 37 Tahun 2004 Tentang Kepailitan dan Penundaan Kewajiban Pembayaran Utang", USU Law Journal 14, no. 1, 2016: 116-126. Law No. 37 of 2004 on the Postponement of Debt Payment Obligations Law No. 4 of 1996 on the Mortgage Right Law No. 42 of 1999 regarding Fiduciary Transfer,

Lie, Gunardi. et.al., "Problematika UU No. 37 Tahun 2004 Tentang Kepailitan dan PKPU Terhadap Bank Sebagai Kreditor Separatis", Jurnal Bakti Masyarakat Indonesia 2, no. 2, 2019: 159-168, DOI: 10.24912/jbmi.v2i2.7242. 
Lukmanul Hakim, "The Alternative Model Settlement of Credit Problems in Banking Agencies", Fiat Justisia: Jurnal Ilmu Hukum 12, no. 2, (2018): 143-155, DOI: 10.25041/fiatjustisia.v12no2.1299.

Murniati, R. \& Selvya, D.C. "Separatist Creditors vs. Preferred Creditors Rights in the Bankruptcy Case Based on the Decision of Constitutional Court of 2013", Fiat Justisia: Jurnal Ilmu Hukum 13, no. 3, 2019: 231240, DOI: 10.25041/fiatjustisia.v13no3.1616.

Nadirah, Ida., Nasution, Bismar, "Composition Bankruptcy As Realization Principles of Balance Between Debtor and Creditor", South East Asia Journal of Contemporary Business, Economics and Law 11, no. 4, 2016: 1-10, 1 .

Rahayu Hartini, "Legal Status of Bank Guarantee on Behalf of Third Parties in the Bankruptcy Perspective", Yustisia 6, no. 1, 2017: 190-198, DOI: 10.20961/yustisia.v6i1.11530.

Rully Afraldo Daely, Ramli Siregar, Windha Windha, "Kedudukan Benda Jaminan Yang Dibebani Hak Tanggungan dan Eksekusi Benda Jaminan Dalam Hal Debitur Pailit”, Transparency, Jurnal Hukum Ekonomi 3, no. 2, 2014: 1-10.

Silalahi, Udin., Claudia. "Kedudukan Kreditor Separatis atas Hak Jaminan Dalam Proses Kepailitan", Masalah-Masalah Hukum 49, no. 1, 2020: 35-47, DOI: 10.14710/mmh.49.1.2020.35-47.

Slamet, S. Redjeki. "Perlindungan Hukum dan Kedudukan Kreditor Separatis Dalam Hal Terjadi Kepailitan Terhadap Debitor", Forum Ilmiah Jurnal Bunga Rampai 13, no. 1, 2016: 104-114.

Sukarta, I. Wayan. "Kedudukan dan Hak Bank terhadap Hak Preferen Upah Buruh Dalam Kepailitan", Jurnal Magister Hukum Udayana (Udayana Master Law Journal) 6, no. 3. (2017): 300-309, DOI: 10.24843/JMHU.2017.v06.i03.p03.

Supreme Court Decree Number 30/KMA/SK/I/2020 Book I on the Guidelines for the Settlement of Requests for Bankrupt and Postponement of Debt Payment Obligations.

Tristam P Moeliono dan Tanius Sebastian, "Tendensi Reduksionis dan Utilitarianis dalam Ilmu Hukum Indonesia: Membaca Ulang Filsafat Hukum Gustav Radbruch", Paper presented at the 5th National Conference of the Indonesian Legal Philosophy Association. Solo, 2015.

Waltraud, S. Scott. "Deferred Cash Payments to Secured Creditors in Cram Down of Chapter 11 Plans: A Matter of Interest", Washinton Law Review 64, no. 4 (1988): 1041-1061,

Yolanda, Nina. "Analisis Yuridis Hak Kreditor Separtis Pemegang Hak Tanggungan Dalam Kepailitan”, Jurnal Litigasi 14, no. 2 (2013): 19371974, DOI: 10.23969/litigasi.v14i2.86. 
Zaini, Z.D., Hakim, Lukmanul. "Prevention and Handling of the Crisis of Financial Systems in Banking Institutions", Fiat Justisia: Jurnal Ilmu Hukum 13, no. 2 (2019): 151-166, DOI: 10.25041/fiatjustisia.v13no2.1567. 
- 